\title{
CSR Aimed at Clients of an Animal Nutrition Business: A Case Study
}

\author{
Julio César López Figueroa ${ }^{1}$, René Daniel Fornés Rivera ${ }^{1} \&$ Elizabeth González Valenzuela ${ }^{1}$ \\ ${ }^{1}$ Department of Industrial Engineering, Instituto Tecnológico de Sonora, Sonora, México \\ Correspondence: Julio César López Figueroa, Department of Industrial Engineering, Instituto Tecnológico de \\ Sonora, Sonora, México. E-mail: julio.lopez@itson.edu.mx
}

Received: June 12, 2017

Accepted: July 20, 2017 Online Published: August 3, 2017

doi:10.5539/jms.v7n3p63

URL: http://doi.org/10.5539/jms.v7n3p63

\begin{abstract}
The objective of the present study is to elaborate a proposal of socially responsible practices aimed at the clients of a Mexican business whose commercial activity is the elaboration of products for animal nutrition and which does not at present have a formal CSR approach in their strategy and therefore lacks important competitive advantages for operating in the business market today.

A literary revision in which the evolution of CSR was presented was carried out as part of this research. We also analyzed three main models for managing CSR in organizations and made a description of some empiric studies of CSR aimed at clients. In the development of the methodology a case study was used, resulting in a diagnosis of the situation of the business with respect to CSR along with a plan for improvement which contains the socially responsible practice proposals suggested in order to create a value relationship with this particular interest group.

It is important to point out that we worked together with the members of the marketing department of the business under study, because it is attending to the needs of the clients, making the employees experience very valuable in determining proposed practices. The results of this research were intended to contribute empirical evidence about the application of CSR in the organizational strategies of emerging-market countries, while increasing existing CSR research in Mexican national industries.
\end{abstract}

Keywords: CSR, stakeholders, clients, Mexico, animal nutrition business

\section{Introduction}

Recently there has been an increase in society's demand for businesess to become transparent in the sustainability of their work and ethical conduct in their business practices with those groups who are affected by their activities. Therefore businesses are interested in adhering to strategic approaches in order to attain sustainable development which translates into wealth for the organization and social benefits for the people (Guibert, 2009). One of these aspects is Corporate Social Responsibility (CSR) which refers to complying with activities with positive repercussions on society (Vergara \& Vicaria, 2012), that is, it involves carrying out social or environmental actions which are beneficial to the community as well as a dialogue and interaction with all of the groups with which the organization has relationships (Cajiga, 2009).

Another reason that organizations adopt said approach is the fact that there is evidence which shows that people prefer to work for those businesses which show high levels of ethics (Daft, 2011). Furthermore, Navarro (2012) points out that a business which does not act responsibly runs the risk of being discredited by consumers, severely affecting the company's corporate image, reputation and finances. Porter \& Kramer $(2002,2006)$ set forth that the philanthropic activities of a business should improve the work environment in the place where the company carries out its operations and add that organizations should aim at forming a value chain in order to implement CSR actions strategically and operatively.

Ventura \& Delgado (2012) point out that the clients are the most important components of the stakeholders of a business since all businesses revolve around the needs of the clients and therefore their satisfaction and degree of confidence is a priority in any organization. This concern is evident in businesses in the (animal or human) nutrition industry, because those companies who do not have mechanisms to inform and protect their clients against any potential harm their products may cause find themselves open to lawsuits and litigations, which can negatively affect their image and their finances.

In Mexico there are 430 plants which produce balanced feed for animals with a value of $\$ 10,200,000,000$ (U.S. 
dollars) which places the country (along with Spain, India and Japan) in the fourth place worldwide in the production of balanced animal feed (AMEPA, 2015). That is why studying CSR aimed at clients of businesses with commercial activity in this field is evidently important. A study carried out by López \& Salazar (2012) in a Mexican business which produces feed for animals showed a lack of a strategy for creating value with clients, and therefore the directive advised integrating the CSR philosophy in order to improve their relationship with their clients and other groups with which they relate.

However, this business showed interest in only implementing CSR practices aimed at the specific interest group as a first step towards this approach and point out that if the results are positive, they would integrate the strategy of socially responsible practices in benefit of all of their stakeholders. It is important to mention that a Mexican business was selected as the object of study of this research because the social and environmental issues involved in CSR are established in the NAFTA negotiations that Mexico is part of, so it is convenient that directives of this country are aware of these topics, besides that studies like this help to a better understanding of the application of the CSR in the strategies of emerging-country organizations (Muller \& Kolk, 2009).

For the purposes of the present paper the concept and evolution of CSR, the definition of stakeholders and some empirical studies of CSR aimed to clients are shown. Moreover, the case study method is applied for the development of the corresponding empirical research, establishing the object of study and the analysis of the data. Finally, the results present a proposed CSR practices plan toward clients, which is recommended to implement in company's strategy.

\section{Revision of Literature}

\subsection{Evolution of CSR}

The evolution of social responsibility has gone from merely being a philosophy aimed at business philanthropy in the middle of the last century (Valor, 2001) (Paladino, 2004) to the creation of today's shared organization value (Porter \& Kramer, 2006). In between, these important events took place: in the 60s the organization is recognized as an institution added to the social system (Ochoa, 2011); during the 80s we have Freeman's theory of Stakeholders (1984) which established that a business could cover the demands of those groups or individuals who are affected by their economic activities (Balaguer, Fernández, \& Muñoz, 2007); in the 90s we find Carroll's (1991) proposal of his model of social performance which establishes a four-part definition of social responsibility in which said responsibilities are: economic, legal, ethical and discretional (Alvarado \& Schlesinger, 2008).

While it is true that Freeman, Carroll and Porter and Kramer's works have their detractors, for the purpose of the present investigation their methodologies establish convenient advantages. Due to the fact that the objective of the present study focuses on relations with clients, Freeman's model helps identify the topics which should be used with said stakeholders and which are the quality and safeness of the products of the organization, customer service and responsible communication (Dopico, Rodríguez, \& González, 2012). Furthermore, García de los Salmones, Pérez, Rodríguez del Bosque, \& San Martín (2008) point out that Carroll's model proposes some ideas for creating value for customers, among which are service and customer satisfaction, besides an analysis of the perception of the former in relation to the economic, legal, ethical and discretional responsibility of the organization. Moreover Porter and Kramer's model of the value chain determine that CSR practices should be conveniently placed in some of the activities of this chain in order to form an integral part of the strategy of the organization.

\subsection{The Concept of CSR and Stakeholders}

It may be observed in related literature that the various definitions of CSR coincide in referring to matters of sustainability, transparency and ethics in organizational practices and their consequences in relation to their stakeholders. This is how some of the authors present the importance of CSR in the strategic management of a business (Guerra, 2007; Araque \& Montero, 2003; Ojeda, 2006), while others such as Cajiga (2009) indicate that this approach establishes itself as a competitive advantage which allows for linking organizational objectives with the objectives of the stakeholders who are defined as those individuals or groups which are impacted by the actions of the business or which impact it as a result of their decisions (Guédez, 2010) and which present a legitimate, direct or indirect interest in the running of the organization (Reyno, 2007).

With respect to the interest group made up of customers, it is important to point out that in recent years the number of consumers who possess greater degrees of information has increased; there is greater environmental consciousness and a preference for natural materials besides the criterion of manufacturing based on human respect (Ventura \& Delgado, 2012). It is important to mention the contribution of Porter \& Kramer (2011) who propose that it is indispensable that businesses do not lose sight of the most basic question: is the product good 
for the customer? It is convenient to point out that today there are businesses aimed at supplying food with greater nutritional value, energy savings, products which are more environmental friendly, etc. The objective is to motivate the customer to choose the aforementioned products, thus resulting in more benefits for society.

\subsection{Empirical Studies of CSR Aimed at the Customers of an Organization}

In specialized literature there are empirical studies made in some of the countries where the practice of socially responsible actions by a company aimed at improving the relationship with customers have been successfully developed up to now (see Table 1). The results of the study carried out by Arriaga, Oviedo \& Camandona (2013) showed that consumers are rational individuals who make multiple decisions about buying based on the satisfaction of various needs, divided into objective and subjective factors. Thus it is necessary for socially responsible businesses to take care of both kinds of needs, making both types of needs compatible with the products and services they offer on the market based on the fundamentals of CSR.

Table 1. Empirical studies on social responsibility aimed at customers

\begin{tabular}{|c|c|c|c|}
\hline Author & Year & Place & Objective \\
\hline $\begin{array}{l}\text { Arriaga, Oviedo \& } \\
\text { Camandona }\end{array}$ & 2013 & Argentina & $\begin{array}{l}\text { 1) To develop the basis on which the behavior of socially responsible businesses are } \\
\text { built; } \\
\text { 2) To determine the factors which influence the behavior of the clients who act } \\
\text { within the framework of responsable consumption. }\end{array}$ \\
\hline Alvarado & 2007 & Venezuela & $\begin{array}{l}\text { 1) To evaluate the management of a business with respect to socially responsible } \\
\text { practices. } \\
\text { 2) To diagnose the levels of satisfaction obtained after applying the programs } \\
\text { designed to benefit stakeholders. }\end{array}$ \\
\hline Reyno & 2007 & Chile & $\begin{array}{l}\text { To propose the use of social responsibility in a business as a method for creating } \\
\text { value and not only as a contribution to the environment so that it would be better } \\
\text { perceived. }\end{array}$ \\
\hline $\begin{array}{l}\text { Habel, Schons, } \\
\text { Alavi \& Wieseke }\end{array}$ & 2016 & United States & $\begin{array}{l}\text { To analyze the relationship between the CSR commitment of companies and the } \\
\text { perception of customers in the establishment of prices. }\end{array}$ \\
\hline $\begin{array}{l}\text { Lienbacher, Holweg, } \\
\text { Rychly \& Schnedlitz }\end{array}$ & 2013 & United States & $\begin{array}{l}\text { To study the awareness and importance of CSR from a consumer perspective in the } \\
\text { food retail sector. }\end{array}$ \\
\hline Ferrell & 2004 & United States & $\begin{array}{l}\text { To analyze and understand customers' expressed and latent needs and develop } \\
\text { solutions that are superior to these needs. }\end{array}$ \\
\hline $\begin{array}{l}\text { Korschun, } \\
\text { Bhattacharya } \\
\text { Swain }\end{array}$ & 2016 & United States & To determine if CSR improves frontliners' job performance \\
\hline Maignan \& Ferrell & 2004 & United States & $\begin{array}{l}\text { To propose that marketers contribute to the successful management of CSR by } \\
\text { expanding their focus beyond consumers to include other stakeholders and grouping } \\
\text { various CSR initiatives }\end{array}$ \\
\hline $\begin{array}{l}\text { Moruff, Adebayo \& } \\
\text { Ogunshola }\end{array}$ & 2017 & United States & $\begin{array}{l}\text { To study the overall effect of corporate social responsibility on customers' loyalty } \\
\text { and retention. }\end{array}$ \\
\hline
\end{tabular}

Source: Own elaboration.

The results of the study carried out by Arriaga, Oviedo \& Camandona (2013) showed that consumers make multiple decisions about buying based on the satisfaction of various needs, thus it is necessary for socially responsible businesses to take care of both kinds of needs, making both types of needs compatible with the products and services they offer on the market based on the fundamentals of CSR. Moreover Alvarado (2007) carried out a study in which he found that, in the specific case of responsibility towards clients and consumers, a business should have a constant concern for developing trustworthy products and services which reduce to a minimum risks to the health of consumers and providing information on the potential harm the products may cause.

Reyno's research (2007) reached the conclusion that socially responsible practices provide competitive advantages for the organization and can be managed by way of tools such as social marketing, defined as the process by which a company adopts their decisions on marketing with a triple objective: business interest, customer satisfaction and customers and society's long-term wellbeing. Also Habel, Schons, Alavi \& Wieseke (2016) obtained as results the suggestion that the directives should ensure that customers perceive that the motives of a company to participate in CSR actions are made from an honest perspective, using strategies such 
as making explicit statements that the expense of social responsibility is extracted from the high salaries of the administration, the advertising budgets or the profits of the company.

The study of Lienbacher, Holweg, Rychly \& Schnedlitz (2013) pointed out that consumers gain knowledge of the CSR activities of food companies through independent communications (leaflets or by word of mouth) and not by reports or web content of these businesses, so it should be considered critically whether the ratio of entry and exit of the cost to communicate CSR and the impact on consumer behavior are at least balanced, otherwise the communication strategy should be rethinked. Besides Ferrell (2004) concluded in his research that consumers perceive an overlap between organizational attributes and their individual attributes, in other words, consumers often look for organizational images that are congruent with their own identity, otherwise it may occur that individuals perceive a conflict between their defining attributes and the attributes that define the organization, which will result in negative perceptions of the organization.

Korschun, Bhattacharya \& Swain (2016) manifest in their work that CSR activities such as charitable donation, environmental programs and ethical practices can motivate both frontline employees and customers, increasing in the former their productivity and obtaining in the latter their preference for the organization's products. In the same way Maignan \& Ferrell (2004) encourage marketers to focus not only on customers CSR needs but also on other stakeholders, noting further that in order to promulgate its commitment to CSR companies must adopt a solid set of principles and processes that systematically address the demands and assurance of the support of stakeholders. Furthermore Moruff, Adebayo, \& Ogunshola (2017) established that it is important to strategically position CSR to command customer loyalty and retention, through adequate dissemination of information on the activities of the company and ensuring that such programs and activities touch the very essence of the life of the average member of the community and society in general.

\subsection{CSR in Mexico}

In Mexico the main organism which promotes CSR is the Centro Mexicano de Filantropía (Cemefi), a civic organization founded in 1988 and whose mission is stated as the promotion of philanthropic, committed and socially responsible participation of citizens, social organizations and businesses in order to create a more equal, supportive and prosperous society. In Mexico we also have AliaRSE which is the alliance of COPARMEX, CCE, CONCAMIN, USEM Confederation, Cemefi, Caux Round Table Mexico and Impulsa, which with commitment and interest promotes corporate social responsibility (AliaRSE por Mexico, 2014).

Cemefi and AliaRSE annually award the Distintivo ESR (Socially Responsible Business Award) which accredits those businesses which have committed, publically and voluntarily, to manage CSR as part of their strategic business culture. Said standing must be reconfirmed each year in order to keep the culture of CSR of the company valid (Cemefi, 2016). The number of businesses that have received the ESR has increased considerably year after year; in 2001 (the first year the distinction was given) 17 endeavors received the award while in 2016, 1,228 businesses were included (Cemefi, 2016). This shows the continued growth and interest by national organizations to adhere to the principles of CSR in order to reinforce their competitive advantages.

\subsection{Sectoralization of CSR in Mexico}

According to Caamal, Ávila \& Ramírez (2010) the largest number of socially responsible businesses in Mexico belongs to the tertiary and service sectors, followed in second place by the industrial and secondary sectors and in last place we find the primary or agricultural sector. Companies which produce animal feed belong to the secondary sector and consist of 507 economic units in this country, which produce a gross total of $\$ 33,852,661,000.00$ (Mexican pesos), representing a gross added value of $\$ 5,256,302,000.00$ (Mexican pesos) which establish its important strategy by virtue of its contribution to the national economy (López, Contreras \& Molina, 2011).

A sectorial analysis made by the agency ResponSable (2014) in the Mexican Food and Beverage industry showed clear concerns of businesses in matters of: (1) the quality and phytosanitary protection of foods, (2) transparency in the origin and/or characteristics of foods and beverages, (3) the development of local suppliers, (4) obtaining the certification of the sector (for quality, fair business, organic, denomination of origin, among others), and (5) the use of ingredients and/or substances which are harmful to human health.

\subsection{The Tendencies of Customers towards CSR}

Research carried out by Caamal, Ávila \& Ramírez (2010) show that an ever greater number of consumers identify with socially responsible businesses and, therefore, prefer to acquire their products in these establishments. Thus in countries such as the United States, Argentina and Spain over $80 \%$ of the customers consider themselves to be socially responsible consumers. This socially responsible consumer is described by 
Perdomo, Dueñas \& Villa (2014) as one who in his consumption seeks ways in which to preserve the environment and shows as his main characteristic of consumption the rejection of products which may be harmful to human health, which have non-ecological packaging and which waste energy or of products which use dangerous materials or come from areas where there are species in danger of extinction. An important factor that enables this behavior is the fact that one of the social interactions that influence the actions described is that of the feelings of community within the groups, that is, people can choose to behave in a more sustainable way because makes them feel like members of a community (Moncure \& Burbach, 2013).

When an organization shows a lack of commitment towards social responsibility, this causes the deception of the responsible consumer who to a greater or lesser extent takes concrete action against the interests of that organization. Therefore, it is necessary for companies to begin taking into account the profile of their clients and focus their efforts on creating strategies for attending to these (ever growing) demands (Arredondo, Maldonado, \& De la Garza, 2011). In order to satisfy the demands of these consumers, businesses must perceive CSR as an opportunity to construct a differentiating element which adds social value for its customers (Marquina \& Reficco, 2015), thus increasing the interest of these consumers in their organization who respond with economic compensations as a result of these kinds of initiatives.

\section{Method: Case study}

The method used in the present research was case study, which Yin (2009) points out is capable of studying cases in depth using multiple sources of evidence, which makes it a useful tool for studying descriptive research, since it offers the possibility of investigating the causal complexity in which there are many relevant factors but few observations.

Using this methodology "the case" which is the object of the study consists of how an integrated system interacts within a specific context with its own characteristics, which are studied by way of information provided by people or documents that have a relationship to the issue (Bernal, 2010). That is to say, it is an investigation of an individual, group, organization or society viewed and analyzed as an entity through extensive descriptions and analysis (Mertens, 2005, cited by Hernándex, Fernández, \& Baptista, 2014).

For the purpose of this paper, only a case study of a company that does not have formally integrated in its strategy the CSR approach was analyzed. Although experts point out that using a single case study is not convenient, Flyvbjerg (2006) states that it is incorrect to consider that it cannot be generalized on the basis of an individual case or that propositions and theories cannot be developed on the basis of specific case studies. This author explains that it can be generalized in a single case and that this case study is useful for the development of science as a complement or alternative to another method, and adds that the problems presented in the summary of case studies are a consequence of the reality studied rather than by the use of the case study as research method.

\subsection{Object of Study}

The present study was carried out in a Mexican company in the animal feed industry located in Ciudad Obregón, Sonora, Mexico. The company has 250 employees, making it a large business, leader in its field with nearly 40 years' experience in producing feed used by the livestock and aquaculture producers in northwestern and central Mexico.

The company was founded in 1977 in order to promote animal health and nutrition. Today it has alliances with foreign organizations which back it up in aspects of investigation and the development of technology for animal nutrition. The concern for the prosperity of its customers is shown in its organizational mission and vision; thus they are open to adapting new approaches which benefit their relationship with this stakeholder.

In spite of this fact, the business is not formally integrated into CSR management due to the use of resources which prevent them from belonging. However, as a result of a study which was carried out by the business and which produced a proposal for integrating CSR as a strategy (López \& Salazar, 2012), the management was interested in mainly including socially responsible practices to benefit only the interest group is made up of customers, mentioning that if the results proved positive, it would decide to integrally apply the aforementioned approach.

As a result, to begin with a diagnosis was made in order to determine the present-day situation of the business and identify areas of opportunity for the formal implementation of CSR aimed at their customers. Thus, with the results obtained from the diagnosis, a proposal of socially responsible practices which would generate value in the relation with customers in order to obtain the corresponding competitive advantages was made. 


\subsection{Procedure}

Since the purpose of this study is to produce CSR practices in order to improve relations with customers, we work together with the personnel of marketing department because it attends the needs of the company's clients. A total of six participants from this department (one manager and five employees) were interviewed twice a week in the installations of the company over a period of three months.

Semi-structured interviews were used to diagnose the existing situation of CSR related to clients. It was first explained to the six participants that the purpose of these interviews was to obtain information about whether they were carried out in the company activities that, according to organizations related to CSR (GRI, ETHOS, Cemefi, ISO 26000, OECD), they can be regarded as socially responsible practices, and can create social value between a business and its customers. This type of interview was used because it makes it possible to have a plan of questions, but it also allows to asking questions of topics that come out in the conversation. These interviews were applied individually allowing the workers, supported by the experience of their functions, to make complementary comments on any topic they considered appropriate to mention, as a support to the collection of information for the development of this research.

The questions were organized in three categories identified in the literature review as CSR oriented to clients. The first dimension is customer satisfaction assessment, the second dimension is customer participation - complaints and suggestions, and the third dimension is advertising. Some of the questions made were: Does the business have a system for evaluating and following up on the degree of customer satisfaction in aspects such as: labeling and publicity, sales and supply services, post-sale services, use of guarantees of the product/service, environmental aspects of the products/services, and social aspects of the product/service? Does the business have a system which attends to and evaluates claims by clients in aspects such as: labeling and publicity, sales and supply services, post-sale services, use of guarantees of the product/service, environmental aspects of the products/services, and social aspects of the product/service? Full content of the interview is in the Appendix A

\subsection{Data Analysis}

The analysis of the information collected was carried out through the technique of content analysis. Categories were established to group the information and the codified responses of the personnel were placed within them. The same categories identified in the interviews were used to facilitate the analysis process and its corresponding interpretation: satisfaction assessment, customer participation - complaints and suggestions, and advertising.

\section{Results}

\subsection{Results of the Diagnosis}

According to the first category (customer satisfaction assessment), the results of interviews showed that business does not evaluate customer satisfaction with respect to the social and environmental aspects of the products, sales services, and labeling and publicity. This represents a disadvantage for the company since the degree of customer satisfaction and confidence is a priority for building a positive business image and reputation (Ventura $\&$ Delgado, 2012), which would be reflected in a respective increase in earnings. However, the company does carry out an analysis of customer satisfaction with respect to their opinion of the safe use of the products and post-sales service.

Regarding the second category (customer participation - complaints and suggestions), personnel of marketing department exposed that business lacks a system which would attend to and evaluate customers' complaints on social and environmental matters as well as safe use, post-sales services, sales services and labeling and publicity of the products which they market. Furthermore, the company does not have a system for collecting and evaluate customers' suggestions in social and environmental matters as well as safe use, post-sales services, sales services and labeling and publicity of their products. This situation obstructs the process of re-imaging new products that would lead to the creation (together with clients) of shared value which reconcile organizations with society (Porter \& Kramer, 2011). If attentions is not paid to customers' complaints and suggestions, valuable information which could be used for identifying areas for improving the business and reacting efficiently to ever-changing tendencies of business is lost.

Moreover, in regard to consumer education, marketing department does not have a program aimed at educating the clients on the risks and side effects of the products which the organization markets, and the business does not provide customers with information about their products on their labels corresponding to social-environmental aspects nor post-sales' obligations. This places the business in a vulnerable situation for possible lawsuits which would bring about financial losses due to the payment of compensations as well as the immediate loss of clients' 
preference and a diminished corporate reputation represented by a decrease in financial utilities. Ojeda (2006) is very clear in pointing out that entities which do not respect fair play may be sanctioned with discredit in the market which translates into losses of images, clients and utilities.

In relation to the third category (advertising) the interviews point out that business promotes its products using advertising which does not create deceiving images, which does not project offensive messages and which maintains a code of respect towards its competitors. Furthermore, the business has a policy which regulates the ethics of advertising activities that are used to promote the sales of the products the organization produces with respect to social-environmental aspects and post-sales' obligations. Likewise, clients' opinions are taken into account only when decisions are made about design or the improvement of new products made by the company; in addition, the business carries out only partial training of its employees on matters of relations with clients and also partially promotes sales practices with ethical criteria.

Nevertheless, the company does not provide customers with information on the labeling about socio-environmental aspects of the product or on post sale obligations. In addition, business does not provide clients with information of CSR activities which the company has or is carrying out, nor does it have any channel by means of which customers may be informed of the functioning and operations of the organization, and does not examine their advertising campaigns in order to determine whether they are in keeping with their organizational values. Consistent with Giuliani, Monteiro, Zambón, Betanho, \& Lima (2012) it would be wise for management to make an advertising plan based on social marketing, because this approach is indispensable for obtaining better devolvement in client-business relation.

\subsection{Proposed CSR Practices for Improving Relations with Clients}

Using the information from the diagnosis and in conjunction with the employees of the marketing department and thanks to valuable information they could provide for the study due to their experience in this area, areas of opportunity for implementing CSR were identified in order to create value with the business' clients, proposing the following socially responsible activities (see Table 2).

Table 2. Proposed CSR practices focused on the customers of the business which is the object of our study

\begin{tabular}{|c|c|c|c|}
\hline OBJETIVE & ACTIVITY & PERSON RESPONSIBLE & FOLLOW-UP \\
\hline \multirow{2}{*}{$\begin{array}{l}\text { Evaluation and } \\
\text { follow-up of } \\
\text { customer } \\
\text { satisfaction }\end{array}$} & $\begin{array}{l}\text { Prepare a catalogue of clients, classifying them according to } \\
\text { length of time as client, volume of sales, degree of faithfulness } \\
\text { and degree of satisfaction }\end{array}$ & $\begin{array}{l}\text { Manager of marketing } \\
\text { department }\end{array}$ & Weekly \\
\hline & $\begin{array}{l}\text { Carrying out surveys in order to find out customers' } \\
\text { expectations and degree of satisfaction }\end{array}$ & $\begin{array}{l}\text { Manager of marketing } \\
\text { department }\end{array}$ & Monthly \\
\hline \multirow{2}{*}{$\begin{array}{l}\text { Attention and } \\
\text { follow-up of } \\
\text { customers' } \\
\text { complaints and } \\
\text { suggestions }\end{array}$} & $\begin{array}{l}\text { Implement a system to receive customers' complaints and } \\
\text { suggestions } 24 / 7\end{array}$ & $\begin{array}{l}\text { Manager of marketing } \\
\text { department }\end{array}$ & Weekly \\
\hline & $\begin{array}{l}\text { Refer to arbitration protocols in order to solve customers' } \\
\text { conflicts and complaints }\end{array}$ & $\begin{array}{l}\text { Manager of marketing } \\
\text { department }\end{array}$ & Weekly \\
\hline \multirow{3}{*}{$\begin{array}{l}\text { Educational } \\
\text { Programs on the } \\
\text { risks and side effects } \\
\text { of the products }\end{array}$} & $\begin{array}{l}\text { Design a media strategy to inform customers of the risks and } \\
\text { side effects of products }\end{array}$ & $\begin{array}{l}\text { Manager of marketing } \\
\text { department }\end{array}$ & Monthly \\
\hline & $\begin{array}{l}\text { Use of labels with clear, simple, truthful and complete } \\
\text { language }\end{array}$ & $\begin{array}{l}\text { Manager of marketing } \\
\text { department }\end{array}$ & Monthly \\
\hline & $\begin{array}{l}\text { Implement a program of personalized consulting for customers } \\
\text { in order to prevent risks and side effects of the products }\end{array}$ & $\begin{array}{l}\text { Manager of marketing } \\
\text { department }\end{array}$ & Bi-weekly \\
\hline $\begin{array}{l}\text { Publicity Program } \\
\text { based on social } \\
\text { marketing }\end{array}$ & $\begin{array}{l}\text { Design a publicity and advertising program based on the } \\
\text { principles of ethics, using transparent and verifiable } \\
\text { information in compliance with corresponding legal } \\
\text { regulations and with the warrantees advertised in the publicity }\end{array}$ & $\begin{array}{l}\text { Manager of marketing } \\
\text { department }\end{array}$ & Bi-anual \\
\hline
\end{tabular}

Source: Own elaboration.

If the director makes the decision to implement these activities in their business strategy, it is proposed that they utilize, to such effect, Porter and Kramer's model of shared value chain. This would prevent the proposed CSR practices from becoming simple, isolated actions which bring on unnecessary expenses for the company. The main reason that justifies the selection of this model lies in the fact that precisely one of the principle activities of the value chain is one that refers to the sales and marketing department, in charge of all of the organizational operations related to customers (see Figure 1). 


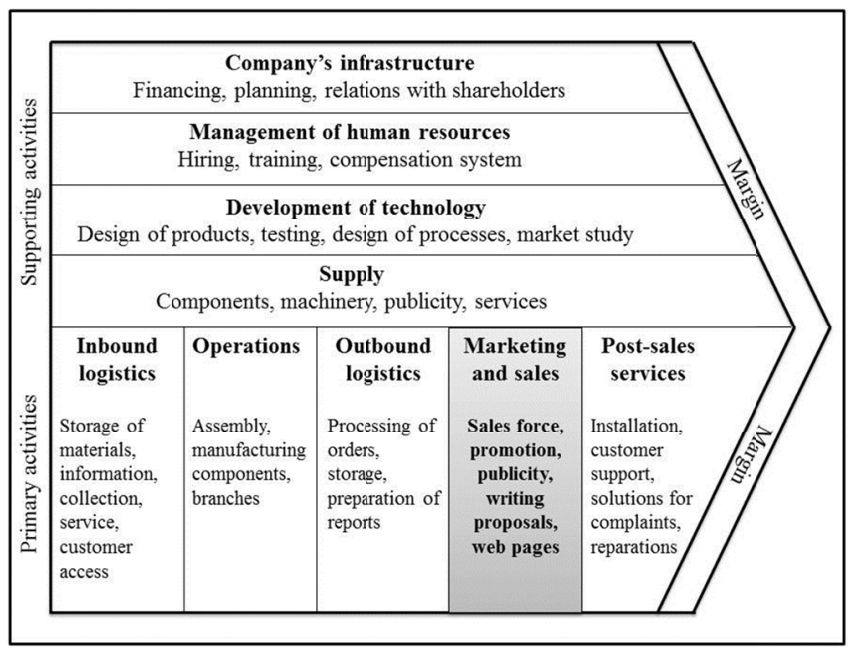

Figure 1. Sales and marketing activities in the value chain

Source: Own elaboration using Porter and Kramer's (2006) information.

Integrating the proposed practices into marketing and sales activity would generate social value towards customers and as a result present a win-win relationship between customers and the company that would bring about indispensable competitive advantages for satisfying today's ever more demanding markets, making it possible for the organization to consolidate its image, reputation and rentability.

\section{Conclusions}

It is true that incorporating CSR may imply making investments -at times not minor- added to the efforts of learning a new way of thinking and doing things which may cause resistance to change, in the beginning preventing people from seeing the great benefits these changes will produce in the company as well as for stakeholders.

However, while this situation may arise in any kind of business, in the specific case of the company we have analyzed in the present investigation (a Mexican company which produces animal feed and that is not integrated into this approach) it infers an additional inconvenience due to the fact that the nature of their line of business places them in a situation of greater risk of possible negative legal problems since they lack programs which inform their consumers of the risk of consuming their products as well as the lack of publicity which is noted for its ethical character in informing of said risks.

Due to the aforementioned reasons, in this study we analyzed Freeman, Carroll and Porter and Kramer's models as means for managing CSR actions aimed at improving relationships between the company under study and their customers. While it is true that ideally socially responsible practices would have been proposed for all stakeholders, the organization accepted to participate first in generating proposals aimed only at the aforementioned interest group due to the work, time and costs involved.

On the other hand, the willingness expressed by the company to venture into CSR towards customers is due to the fact that their competitors are mainly foreign companies, some of whom already have experience in managing CSR and have the support of responsible consumers who prefer to enter into business relationships with organizations who show real concern for the effects their products cause animals, and in consequence, the people who consume the meat of these animals. One of the dangers which is always present in these kinds of initiatives is that the best intentions of a business end up being no more than isolated actions, due to the lack mechanisms for formalization, resulting in useless efforts that only bring on financial spending without any profitability for the organization.

In order avoid this kind of situation, in the present project we have explained the convenience of using Porter and Kramer's chain of value as a means for including the proposed CSR actions in the company's strategy (specifically in their primary activity related to marketing and sales). In this way organizational activities which take place in that department will be capable of generating social value towards customers characterized by, among other things, an honest concern for their satisfaction and safety.

Due to the important benefits of CSR, it is recommended that the business analyzed in this project also integrate 
socially responsible practices towards other stakeholders. In this way they would be in an unsurpassable position to continue successfully operating in the business world. Besides, in the specialized bibliography there have been few studies made with respect to CSR and business which produce animal feed and therefore the results of this investigation are important for this industrial sector since they may serve as a guide for developing future studies.

It is possible to sum up that CSR is a concept which, despite its appeal to the business world, continues to have drawbacks which show that lack of trust towards the "honest attitude" of organizations in spending part of their resources on the search for improving relationships with all of the groups affected by their work activities. This distrust resides in the fact that some view these business attitudes as a simple business strategy for engaging more and better followers to whom they may sell their products by means of marketing campaigns disguised as sustainable.

However, it is undeniable that a business which integrates CSR into its strategic plans certainly shows concern for contributing to improving their and their stakeholders' lives. As examples, we may mention the cases of Novo Nordisk (a Danish company which stands out for its support of educational programs and scholarships for low income students), Natura Cosméticos (a Brazilian company committed to protecting the environment and to the reconstruction of the forest system) and Stratoil (a Norwegian business which produces gas and oil and which spends a large part of its investments on improving the communities where it does business (Corporate Knights, 2013).

Specialized literature shows that the XXI century is characterized by the existence of a society which demands greater transparency from organizations in their labor practices. Nevertheless, this should not be seen as an obstacle for good relationships between businesses and society, but rather as a great opportunity for organizations to reconcile with an environment which they have historically polluted and discriminated against. In the words of Senge (2001) "increasingly, society will demand that businesses develop a broader view, in which those businesses that lead the way in these changes will obtain greater credibility within their societies."

This paper was developed in a business whose commercial activity consists in the elaboration of products for animal nutrition, so that the results obtained cannot be considered definitive for the industry in general. On the other hand, this study is focused towards the stakeholders formed by the clients, so it is possible that to develop it towards other groups of interest with the specifications described in this research will cause a variation in the obtained results.

\section{References}

AliaRSE por México. (2014). La RSE en México. Retrieved from http://www.aliarse.org

Alvarado, A., \& Schlesinger, M. (2008). Dimensionalidad de la responsabilidad social empresarial percibida y sus efectos sobre la imagen y la reputación: una aproximación desde el modelo de Carroll. EstudiosGerenciales, 24(108), julio-septiembre, 37-59. Universidad ICESI. Colombia. https://doi.org/10.1016/S0123-5923(08)70043-3

Alvarado, W. (2007). Evaluación de la gestión de la responsabilidad social empresarial en la empresa PRECA, S.A. y de sus sucursales ubicadas en el estado Lara. Universidad Centroccidental "Lisandro Alvarado". Retrieved from http://bibadm.ucla.edu.ve/edocs_baducla/tesis/P756.pdf

Araque, R., \& Montero, J. (2003). La responsabilidad social de la empresa en el ámbito del marketing: algunas reflexiones y propuestas. Papeles de Ética y Dirección, No. 8. Retrieved from www.eben-spain.org/docs/Papeles/XI/2_Araque.pdf

Arredondo, F., Maldonado, V., \& De la Garza, J. (2011). El consumidor ante la responsabilidad socialcorporativa. Actitudes según edad y género. Cuadernos de Administración, 24(43), julio-diciembre, 285-305. Bogotá: Pontificia Universidad Javeriana. Retrieved from http://www.redalyc.org/articulo.oa?id=20521435013

Arriaga, M., Oviedo, R., \& Camandona, M. (2013). La responsabilidad social empresarial en la relación "empresa-cliente". SaberEs No. $5 . \quad$ Retrieved from http://www.saberes.fcecon.unr.edu.ar/index.php/revista/article/view/87/192

Asociación Mexicana de Productores de Alimentos A.C. (AMEPA). (2015, Marzo). La industria de alimento para animales en México y su regulación sanitaria. Asociación Latinoamericana de Plantas de Rendimiento (ALAPRE). Tercer Congreso Internacional, Cancún, México. Retrieved from http://www.alapre.org/Downloads/Presentaciones_ppt_tercera_conferencia/La_Industria_de_Alimento_para _Animales_en_Mexico_-_Regulacion_Sanitaria.pdf 
Balaguer, M., Fernández, M., \& Muñoz, M. (2007). La responsabilidad social de la empresa: relaciones entre la performance social, financiera y bursátil. España: Generalitat Valenciana. Retrieved from http://www.indi.gva.es/documents/161328120/161338410/Responsabilidad_Social_Empresa.pdf/44ce35396b59-4ad8-be60-5b50f382b4dd

Bernal, C. (2010). Metodología de la investigación (3rd ed.). Colombia: PEARSON.

Caamal, I., Ávila, J., \& Ramírez, J. (2010). Tendencias actuales de la responsabilidad social en las empresas en México. Textual, (56), 47-68.

Cajiga, J. (2009). El concepto de Responsabilidad Social Empresarial. Centro Mexicano para la Filantropía. Retrieved from www.cemefi.org/esr/images/stories/pdf/esr/concepto_esr

Carroll, A. B. (1991). The pyramid of Corporate Social Responsability: Towards the moral management $\begin{array}{lllll}\text { oforganizational stakeholders. } & \text { Business } & \text { Horizons, } & 34(4), & 38 .\end{array}$ https://doi.org/10.1016/0007-6813(91)90005-G

Centro Mexicano de Filantropía (Cemefi). (2016). Distintivo ESR. Retrieved from http://www.cemefi.org/esr/

Corporate Knights. (2013). Global 100 announced at the World Economic Forum in Davos. Retrieved from http:/www.corporateknights,com/article/global-100-announced-world-economic-forum-davos

Daft, R. (2011). Teoría y diseño organizacional (10th ed.). México: CENGAGE

Dopico, A., Rodríguez, R., \& González, E. (2012). La responsabilidad social empresarial y los stakeholders: unanálisis clúster. Revista Galega de Economía, 21(1), 1-17. Universidad de Santiago deCompostela, España. Retrieved from http://www.redalyc.org/pdf/391/39123194005.pdf

Ferrell, O. (2004). Business ethics and customer stakeholders. https://doi.org/10.5465/AME.2004.13836176

Flyvbjerg, B. (2006). Five misunderstandings about case-study research. Qualitative Inquiry, 12(2), $219-245$. https://doi.org/10.1177/1077800405284363

Freeman, R. (1984). Strategic Management: A Stakeholder Approach. USA: Cambridge University Press

García de los Salmones, M., Pérez, A., Rodríguez del Bosque, I., \& San Martín, H. (2008). The influence of corporate social responsibility on financial service evaluations. 7th International Congress MarketingTrenas, Venecia, 17 y 19 de $\quad$ Enero. Retrieved from http://www.escp-eap.net/conferences/marketing/2008_cp/Materiali/Paper/Fr/GarciadelosSalmones_Perez_R odriguezdelBosque_SanMartin pdf

Giuliani, A., Monteiro, T., Zambón, M., Betanho, C., \& Lima, L. (2012). El marketing social, el marketingrelacionado con causas sociales y la responsabilidad social empresarial el caso del supermercado Pão de Açúcar, de Brasil. Retrieved from http://www.redalyc.org/articulo.oa?id=87724146003

Guédez, V. (2010). Grupos de interés y responsabilidad social empresarial. Ganar-ganar. Retrieved from

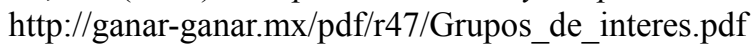

Guerra, A. (2007). De la responsabilidad social empresarial, a la ética en el cambio organizacional. Compendium, número 18, Julio. Retrieved from http://www.ucla.edu.ve/dac/Compendium/revista18/05_AGuerra.pdf

Guibert, J. (2009). Responsabilidad Social Empresarial: competitividad y casos de buenas prácticas en PYMES. España: Deusto Publicaciones

Habel, J., Schons, L., Alavi, S., \& Wieseke, J. (2016). Warm Glow or Extra Charge? The Ambivalent Effect of Corporate Social Responsibility Activities on Customers' Perceived Price Fairness. Journal of Marketing, 80(1), 84. https://doi.org/10.1509/jm.14.0389

Hernández, R., Fernández, C., \& Baptista, P. (2014). Metodología de la investigación (6th ed.). México: McGraw-Hill

Korschun, D., Bhattacharya, C., \& Swain, S. (2016). CSR and the Frontline Context: How Social Programs Improve Customer Service. GfK Marketing Intelligence Review, 8(1), 24-29. ProQuest. Web. 8 July 2017. https://doi.org/10.1515/gfkmir-2016-0004

Lienbacher, E., Holweg, C., Rychly, N., \& Schnedlitz, P. (2013). CSR in food retailing: what's really on customers' minds? AMA Winter Educators' Conference Proceedings, 24, 235-243. Retrieved from https://www.researchgate.net/publication/269096777_CSR_IN_FOOD_RETAILING_WHAT'S_REALLY_ 


\section{ON_CUSTOMERS'_MINDS}

López, A., Contreras, R., \& Molina, R. (2011). La responsabilidad social empresarial como estrategia de competitividad en el sector alimentario. Cuadernos de Administración, 24(Julio-Diciembre). Retrieved from $\mathrm{http}: / /$ www.redalyc.org/articulo.oa? id=20521435012> ISSN 0120-3592

López, J., \& Salazar, L. (2012). Planeación estratégica con enfoque Mega. México: Instituto Tecnológico deSonora

Maignan, I., \& Ferrell, O. (2004). Corporate social responsibility and marketing: An integrative framework. Journal of the Academy of Marketing Science, 32(1), 3-19. https://doi.org/10.1177/0092070303258971

Marquina, P., \& Reficco, E. (2015). Impacto de la responsabilidad social empresarial en el comportamiento decompra y disposición a pagar de consumidores bogotanos. Estudios Gerenciales, 31 (Octubre-Diciembre). https://doi.org/10.1016/j.estger.2015.10.001

Mertens, D. (2005). Research and evaluation in education and psychology: Integrating diversity with quantitative, qualitative, and mixed methods (2nd ed.). Thousand Oaks, CA, USA: SAGE

Moncure, S., \& Burbach, M. (2013). Social Reinforcement of Environmentally Conscious Consumer Behavior at a Grocery Store Cooperative. Journal of Management and Sustainability, 3(4). https://doi.org/10.5539/jms.v3n4p14

Moruff Sanjo, M., Adebayo, L., \& Ogunshola, B. (2017). Effect of corporate social responsibility (CSR) on customers' loyalty and retention. BVIMSR Journal of Management Research, 9(1), 1.

Muller, A., \& Kolk, A. (2009). CSR performance in emerging markets evidence from Mexico. Journal of Business Ethics, 85, 325-337. https://doi.org/10.1007/s10551-008-9735-y

Navarro, F. (2012). Responsabilidad Social Corporativa: teoria y práctica (2nd ed.). España: ESIC Editorial

Ochoa, B. (2011). Responsabilidad social empresarial: un modelo integral para Sonora. México: InstitutoTecnológico de Sonora.

Ojeda, P. (2006). Responsabilidad Social Empresarial: una visión alternativa del caso de la planta de celulosa. Valdivia. Chile: Ediciones Universidad del Bio-Bio.

Paladino, M. (2004). La responsabilidad de la empresa en la sociedad. Argentina: ARIEL.

Perdomo, J., Dueñas, S., \& Villa, L. (2014). El concepto de consumo socialmente responsable y su medición. Retrieved from http://www.redalyc.org/articulo.oa?id=21231380009

Porter, M., \& Kramer, M. (2002). La ventaja competitiva de la filantropía estratégica. Harvard Business Review. Retrieved from https://hbr.org/2002/12/the-competitive-advantage-of-corporate-philanthropy

Porter, M., \& Kramer, M. (2006). Estrategia y sociedad. Harvard Business Review. América Latina. Retrieved from http://www.fundacionseres.org/Lists/Informes/Attachments/12/Estrategia\%20y20\%Sociedad.pdf

Porter, M., \& Kramer, M. (2011). La creación de valor compartido. Harvard Business Review. Retrieved from https://hbr.org/2011/01/the-big-idea-creating-shared-value

ResponSable. (2014). La Responsabilidad Social en México desde un enfoque sectorial. Estudio 2014. Retrieved from

http://www.responsable.net/estudios/mexico/La_Responsabilidad_Social_en_Mexico_desde_un_enfoque_s ectorial 2014.html

Reyno, M. (2007). Responsabilidad social empresarial (RSE) como ventaja competitiva. Universidad $\begin{array}{lllll}\text { TécnicaFederico Santa } & \text { María. } & \text { Retrieved }\end{array}$ www.itescam.edu.mx/principal/sylabus/fpdb/recursos/r79731.PDF

Senge, P. (2001). Las personas no son recursos. Interview with Executive Digest Magazine, July, 58-62.

Valor, M. (2001). Responsabilidad social de la empresa, marketing de relaciones y política de recursos humanos: el gasto social de la empresa. Papeles de Ética, Economía y Dirección. Retrieved from http://www.eben-spain.org/docs/Papeles/IX/5_Valor0.pdf

Ventura, B., \& Delgado, S. (2012). Recursos humanos y responsabilidad social corporativa. España: EdicionesParaninfo, S. A.

Vergara M., \& Vicaría, L. (2009). Ser o aparentar la Responsabilidad Social Empresarial en Colombia. $\begin{array}{lllll}\text { Universidad Javeriana } & \text { de } & \text { Bogotá } & \text { Retrieved }\end{array}$ 
www.javeriana.edu.co/biblos/tesis/comunicacion/tesis250.pdf

Yin, R. (2009). Case study research: design and methods (4th ed.). USA: Thousand Oaks: SAGE Publications, Inc.

\section{Appendix A}

\section{Content of the Interview}

\begin{tabular}{|c|c|}
\hline Category & Question \\
\hline $\begin{array}{l}\text { Customer satisfaction } \\
\text { assessment }\end{array}$ & $\begin{array}{l}\text { 1. Does the business have a system for evaluating and following up on the degree of customer satisfaction in } \\
\text { aspects such as: labeling and publicity, sales and supply services, post-sale services, use of guarantees of the } \\
\text { product/service, environmental aspects of the products/services, and social aspects of the product/service? }\end{array}$ \\
\hline \multirow[t]{3}{*}{$\begin{array}{l}\text { Customer } \\
\text { participation-complaints } \\
\text { and suggestions }\end{array}$} & $\begin{array}{l}\text { 2. Does the business have a system which attends to and evaluates claims by clients in aspects such as: } \\
\text { labeling and publicity, sales and supply services, post-sale services, use of guarantees of the product/service, } \\
\text { environmental aspects of the products/services, and social aspects of the product/service? }\end{array}$ \\
\hline & $\begin{array}{l}\text { 3. Does the business have a system for collecting and evaluating customers' suggestions in aspects such as: } \\
\text { labeling and publicity, sales and supply services, post-sale services, use of guarantees of the product/service, } \\
\text { environmental aspects of the products/services, and social aspects of the product/service? }\end{array}$ \\
\hline & $\begin{array}{l}\text { 4. Does the company have educational programs for their consumers on the risks and side effects of their } \\
\text { products or services? }\end{array}$ \\
\hline \multirow[t]{9}{*}{ Advertising } & $\begin{array}{l}\text { 5. Does the company advertise its products and/or services using publicity which does not create deceptive } \\
\text { images, which does not contain offensive messages and which maintains a code of respect for its competitors? }\end{array}$ \\
\hline & $\begin{array}{l}\text { 6. Does the company inform the customer on its labels of the social-environmental aspects or post-sales } \\
\text { obligations of its products? }\end{array}$ \\
\hline & 7. Does the company have an ethical policy in matters of publicity? \\
\hline & 8. Does the company inform its customers of CSR activities it has or is carrying out? \\
\hline & $\begin{array}{l}\text { 9. Has the company established a channel by which clients or customers may obtain information on the } \\
\text { workings of the business and on the results of their operation? }\end{array}$ \\
\hline & $\begin{array}{l}\text { 10. Is the opinion of the clients taken into account through studies in order to design and improve new } \\
\text { products/services? }\end{array}$ \\
\hline & 11. Does the company regularly train its collaborators in matters related to "Customer Services"? \\
\hline & 12. Does the business promote sales practices with ethical criteria? \\
\hline & $\begin{array}{l}\text { 13. Are publicity campaigns examined prior to use in order to verify that they are in keeping with the values } \\
\text { of the business? }\end{array}$ \\
\hline
\end{tabular}

\section{Copyrights}

Copyright for this article is retained by the author(s), with first publication rights granted to the journal.

This is an open-access article distributed under the terms and conditions of the Creative Commons Attribution license (http://creativecommons.org/licenses/by/4.0/). 